\title{
Analisis Pengaruh Komposisi Serbuk terhadap Sifat Fisis dan Mekanis Komposit Papan Partikel Dari Tandan Kosong Kelapa Sawit, Serbuk Kayu dan Tempurung Kelapa
}

\author{
Wirnu Hidanto*, Mora \\ Laboratorium Fisika Material, Jurusan Fisika \\ Fakultas Matematika dan Ilmu Pengetahuan Alam Universitas Andalas \\ Kampus UNAND Limau Manis, Padang, 25163, Indonesia \\ *whdanto2@gmail.com
}

\begin{abstract}
ABSTRAK
Penelitian ini bertujuan untuk mengetahui pengaruh komposisi tandan kosong kelapa sawit, serbuk kayu, dan tempurung kelapa terhadap sifat fisis dan mekanis papan partikel. Sifat fisis yang diuji meliputi densitas, kadar air, dan daya serap air sedangkan pengujian sifat mekanis meliputi Modulus of Elasticity (MOE) dan Modulus of Rupture (MOR). Ukuran partikel yang digunakan adalah partikel tandan kosong kelapa sawit lolos ayakan 50 mesh, serbuk kayu dan tempurung kelapa lolos ayakan 100 mesh. Hasil ayakan dibagi lima komposisi dengan rasio persentase dari serbuk kayu meranti:tempurung kelapa yaitu 25:5, 20:10, 15:15, 10:20, 5:25. Hasil uji sifat fisis seperti densitas terendah $0,97 \mathrm{~g} / \mathrm{cm}^{3}$ pada komposisi $25: 5$ sedangkan densitas tertinggi $1,09 \mathrm{~g} / \mathrm{cm}^{3}$ pada komposisi 5:25, kadar air papan terendah 0,89\% pada komposisi 5:25 sedangkan kadar air tertinggi $1,85 \%$ pada komposisi $25: 5$, nilai daya serap air terendah $15,17 \%$ pada komposisi 5:25 sedangkan daya serap air tertinggi 34,47\% pada komposisi 25:5. Hasil uji sifat mekanis seperti MOE terendah sebesar $396,26 \mathrm{~kg} / \mathrm{cm}^{2}$ pada komposisi 10:20 sedangkan MOE tertinggi sebesar 984,93 kg/ $\mathrm{cm}^{2}$ pada komposisi

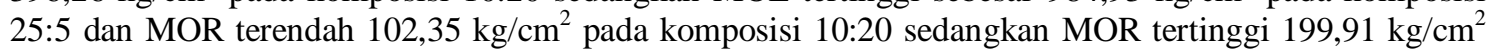
pada komposisi 25:5. Sifat fisis dan mekanis papan yang didapatkan telah memenuhi standar SNI 032105-2006 kecuali untuk pengujian densitas dan MOE.

Kata kunci: papan partikel, sifat fisis, sifat mekanis, tandan kosong kelapa sawit, serbuk kayu, tempurung kelapa.
\end{abstract}

\begin{abstract}
The purpose of this research is to investigate the effect of composition of oil palm empty fruit bunch, sawdust, and coconut shell particle on physical and mechanical properties of particle board. The measured physical properties were density, water content, and water absorption while the mechanical characteristics consist of Modulus of Elasticity (MOE) and Modulus of Rupture (MOR). The particles size used were oil palm empty bunches that pass 50 mesh, sawdust and coconut shell pass 100 mesh. The filler microparticles which procured subsequently separated to five compositions within specified volumetric percentage ratio (sawdust:coconut shell) namely 25:5, 20:10, 15:15, 10:20, 5:25. The result of physical characteristics that shown the lowest density of $0.97 \mathrm{~g} / \mathrm{cm}^{3}$ for ratio 25.5 while the highest density of 1.09 $\mathrm{g} / \mathrm{cm}^{3}$ for ratio 5:25. The lowest water content of 0.89\% for ratio 5:25 while the highest water content of $1.85 \%$ for ratio $25: 5$. The lowest water absorption of $15.17 \%$ for ratio 5:25 while the highest water absorption of 34.47\% for ratio 25:5. The result of mechanical characteristics that shown the lowest MOE value of $396.26 \mathrm{~kg} / \mathrm{cm}^{2}$ for ratio 5:25 while the highest value of $984.93 \mathrm{~kg} / \mathrm{cm}^{2}$ for ratio $25: 5$. The lowest MOR value of $102.35 \mathrm{~kg} / \mathrm{cm}^{2}$ for ratio 10:20 while the highest MOR value of $199.91 \mathrm{~kg} / \mathrm{cm}^{2}$ for ratio 25:5. The physical and mechanical characteristics of the particle board obtained in the test full fill SNI 03-2105-2006 standard except for density and MOE.

Keywords: particle board, physical properties, mechanical properties, oil palm empty fruit bunch, sawdust, coconut shell.
\end{abstract}

\section{PENDAHULUAN}

Kebutuhan manusia terhadap kayu mengalami peningkatan yang signifikan. Eksploitasi berlebihan terhadap kayu-kayu hutan mengakibatkan sumber daya hutan semakin berkurang. Menurut Fatanah (2011), ketergantungan akan bahan kayu harus segera ditanggulangi agar tidak mengurangi hasil hutan. Salah satu upaya yang dapat dilakukan adalah menggantikan kayu dengan material lain. Material lain yang digunakan tentunya harus mempunyai kualitas yang lebih unggul atau tidak kalah dengan produk kayu yang ada di hutan. Salah satu cara untuk mengatasi pemenuhan kebutuhan akan keperluan kayu tersebut adalah dengan memanfaatkan 
limbah-limbah tumbuhan. Produksi papan buatan berupa papan partikel merupakan salah satu cara untuk memanfaatkan limbah-limbah tumbuhan yang tidak dimanfaatkan secara ekonomis.

Papan partikel merupakan salah satu papan yang dihasilkan dari partikel-partikel kayu dan diikat menggunakan zat perekat. Papan partikel mempunyai beberapa kelebihan dibandingkan dengan kayu seperti bebas mata kayu, tidak mudah pecah dan tidak mudah retak (Maloney, 1997). Pembuatan papan partikel berdasarkan pada pertimbangan ekonomis yaitu untuk memanfaatkan limbah dari berbagai jenis tumbuhan (Roza dkk., 2015).

Indonesia mempunyai lahan sawit kurang lebih 14,03 juta hektar menghasilkan minyak sawit sekitar 37,8 juta ton dengan rata-rata produktivitasnya sekitar 3,6 ton per hektar. Setiap 5 ton buah segar kelapa menghasilkan limbah padat 2,1 ton yang terdiri dari $950 \mathrm{~kg}$ fiber (serat) dan cangkang serta $1.150 \mathrm{~kg}$ tandan kosong (Rizza, 1994). Tandan kosong kelapa sawit memiliki kandungan lignin dan selulosa yang dapat dimanfaatkan sebagai bahan tambahan dalam material komposit yang dapat menambah kekerasan bahan (Kliwon, 2002).

Pembuatan papan partikel berbahan tandan kosong kelap sawit telah dilakukan oleh Cahyana (2014). Nilai MOE hasil penelitiannya berkisar antara $249,42-490,95 \mathrm{~kg} / \mathrm{cm}^{2}$, nilai MOE yang didapat tidak memenuhi standar SNI 03-2105-2006 yang mensyaratkan nilai MOE minimal $20400 \mathrm{~kg} / \mathrm{cm}^{2}$. Purwanto (2016) melakukan penelitian dengan menguji sifat papan partikel dari tandan kosong kelapa sawit dan serbuk kayu dengan perekat urea formaldehida. Nilai MOE yang didapatkan sebesar 1594,88 kg/cm ${ }^{2}$ dan nilai Modulus of Rupture adalah 18,08 $\mathrm{kg} / \mathrm{cm}^{2}$. Nilai MOE dan MOR yang didapatkan tidak memenuhi standar SNI 03-2105-2006. Ini dikarenakan tidak adanya perlakuan pada tandan kosong kelapa sawit, zat ekstraktif yang terdapat pada tandan kelapa sawit bisa mengganggu proses perekatan. Oleh karena itu, perlu diberikan perlakuan pada bahan tandan kosong kelapa sawit dengan cara merendamnya dengan air panas pada suhu $100{ }^{\circ} \mathrm{C}$ sebelum digunakan untuk pembuatan papan partikel.

Irawati (2013) melakukan penelitian tentang pengaruh ukuran partikel tempurung kelapa sebagai pengisi komposit poliester tak jenuh terhadap sifat mekanis dan penyerapan air. Dari penelitian tersebut didapatkan bahwa sifat fisis (kerapatan, kadar air, daya serap air) papan partikel yang diuji telah memenuhi standar SNI 03-2105-2006. Penelitian tersebut menunjukkan bahwa pengisi serbuk tempurung kelapa ukuran 100 mesh mampu meningkatkan MOE sebesar $6083,47 \mathrm{~J} / \mathrm{m}^{3}$ dari poliester murni sebesar $3354,83 \mathrm{~J} / \mathrm{m}^{3}$. Penggabungan partikel ampas tebu dengan tempurung kelapa diharapkan akan memperbaiki sifat fisis dan mekanis papan partikel yang dihasilkan.

\section{METODE}

Bahan yang digunakan dalam penelitian ini adalah tandan kosong kelapa sawit, serbuk kayu meranti, tempurung kelapa dan resin epoksi. Tandan kosong kelapa sawit terlebih dahulu direndam selama 2 jam dengan air panas pada suhu $100{ }^{\circ} \mathrm{C}$ untuk menghilangkan zat ekstraktif yang dapat menghalangi perekat bereaksi dengan komponen selulosa. Tandan kosong kelapa sawit yang telah direndam selama 2 jam, serbuk kayu, dan tempurung kelapa yang digunakan dibersihkan dari sabutnya yang masih menempel dan dijemur dengan cahaya matahari sampai kering, kemudian digiling dengan mesin grinding untuk memperkecil ukuran sehingga mempermudah proses penghalusan dengan ball milling. Tandan kosong kelapa sawit yang sudah digiling kemudian diayak menggunakan ayakan 50 mesh, serbuk kayu meranti dan tempurung kelapa diayak menggunakan ayakan 100 mesh. Hasil ayakan akan digunakan sebagai pengisi papan partikel.

Partikel yang diperoleh dicampur dalam wadah dan diaduk menggunakan mixer hingga homogen sesuai dengan komposisi masing-masing sampel dengan massa total yaitu $90 \mathrm{~g}$. Komposisi sampel divariasikan dengan perbandingan variasi komposisi tandan kosong kelapa sawit : serbuk kayu meranti : tempurung kelapa sebanyak 5 variasi yaitu 40:25:5, 40:20:10, 40:15:15, 40:10:20 dan 40:5:25 dengan komposisi perekat yang tetap 30\%. Sampel yang telah diaduk dituangkan dalam cetakan yang sudah dilapisi aluminium foil. Permukaan sampel diratakan dengan penutup yang tersedia pada cetakan dan ditekan menggunakan hot packing press dengan beban $2000 \mathrm{~kg}$ pada suhu $150^{\circ} \mathrm{C}$ di atas dan bawah selama 10 menit. Sampel dikeringkan minimal selama 24 jam dan dilakukan uji sifat fisis dan uji mekanis. 
Pengujian densitas papan partikel dilakukan dengan cara menimbang massa sampel menggunakan timbangan digital serta mengukur panjang, lebar dan tebal sampel. Pengujian kadar dilakukan dengan mengukur massa sampel dan dipanaskan dalam oven pada suhu $100{ }^{\circ} \mathrm{C}$ selama 10 menit. Pengujian daya serap air dengan cara mengukur massa awal sampel sebelum dimasukkan kedalam wadah yang berisi air selama 24 jam. Pengujian MOE dan MOR dengan memberikan beban tegak lurus terhadap sampel dengan jarak sangga $8 \mathrm{~cm}$. Ukuran sampel yang digunakan untuk densitas, kadar air, MOE, dan MOR adalah 10 × $5 \mathrm{~cm}$, sedangkan ukuran yang digunakan untuk daya serap air adalah $5 \times 5 \mathrm{~cm}$.

Pengujian sifat fisis dan mekanik papan partikel dilakukan berdasarkan standar SNI 032105-2006. Sifat fisis yang duj adalah densitas, kadar air, dan daya serap air. Sedangkan untuk uji sifat mekanis yang diuji adalah MOE dan MOR.

\section{HASIL DAN DISKUSI}

\subsection{Uji Sifat Fisis}

\subsubsection{Densitas}

Gambar 1 menunjukkan nilai densitas papan partikel yang dihasilkan antara 0,97-1,09 $\mathrm{g} / \mathrm{cm}^{3}$. Densitas terendah papan partikel terdapat pada papan dengan komposisi filler 25\%:5\% dengan densitas $0,97 \mathrm{~g} / \mathrm{cm}^{3}$, sedangkan nilai densitas tertinggi papan partikel terdapat pada papan dengan komposisi filler 5\%:25\% dengan densitas $1,09 \mathrm{~g} / \mathrm{cm}^{3}$. Hasil penelitian menunjukkan bahwa penambahan komposisi partikel tempurung kelapa meningkatkan nilai densitas papan partikel yang dihasilkan. Semakin banyak tempurung kelapa yang digunakan semakin tinggi nilai densitasnya. Nilai densitas papan partikel menurun menghampiri nilai yang ditetapkan SNI 03-2105-2006 $\left(0,5-0,9 \mathrm{~g} / \mathrm{cm}^{3}\right)$ seiring dengan bertambahnya komposisi partikel serbuk kayu meranti. Hal ini disebabkan karena berat jenis bahan baku yang digunakan. Berat jenis partikel tempurung kelapa $\left(0,75 \mathrm{~g} / \mathrm{cm}^{3}\right)$ lebih tinggi dibandingkan partikel serbuk kayu meranti $\left(0,21 \mathrm{~g} / \mathrm{cm}^{3}\right)$, sehingga memberikan peningkatan densitas papan partikel pada setiap penambahan komposisi tempurung kelapa. Menurut Maloney (1997) menyatakan bahwa faktor penting yang mempengaruhi nilai densitas papan partikel adalah berat jenis bahan baku.

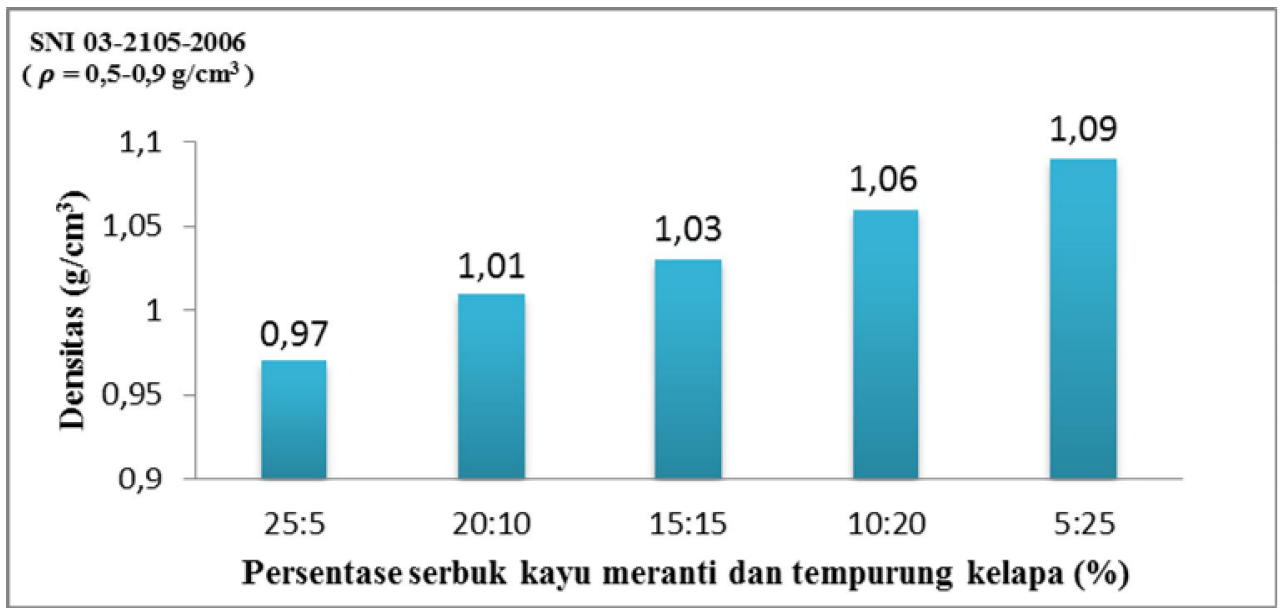

Gambar 1 Pengaruh komposisi serbuk kayu meranti dan tempurung kelapa terhadap densitas papan partikel

Standar SNI 03-2105-2006 menjelaskan bahwa denitas papan partikel yaitu 0,5-0,9 $\mathrm{g} / \mathrm{cm}^{3}$, maka densitas papan partikel yang didapat dalam penelitian ini tidak memenuhi standar mutu yang ditetapkan. Berdasarkan nilai densitas yang didapat untuk semua variasi komposisi papan partikel menunjukkan nilai densitas diatas $0,9 \mathrm{~g} / \mathrm{cm}^{3}$ yang dapat dikategorikan ke dalam papan partikel berkerapatan tinggi dimana nilai densitas papan partikel lebih dari $0,8 \mathrm{~g} / \mathrm{cm}^{3}$ (Maloney, 1997). 


\subsubsection{Kadar Air}

Kadar air papan partikel bergantung pada kondisi udara di sekitarnya, karena papan terdiri atas bahan-bahan yang mengandung lignoselulosa sehingga menyebabkan papan bersifat higroskopis dan menjadi lembab (Iswanto, 2008). Berdasarkan hasil pengukuran didapatkan hasil pengujian kadar air seperti pada Gambar 2.

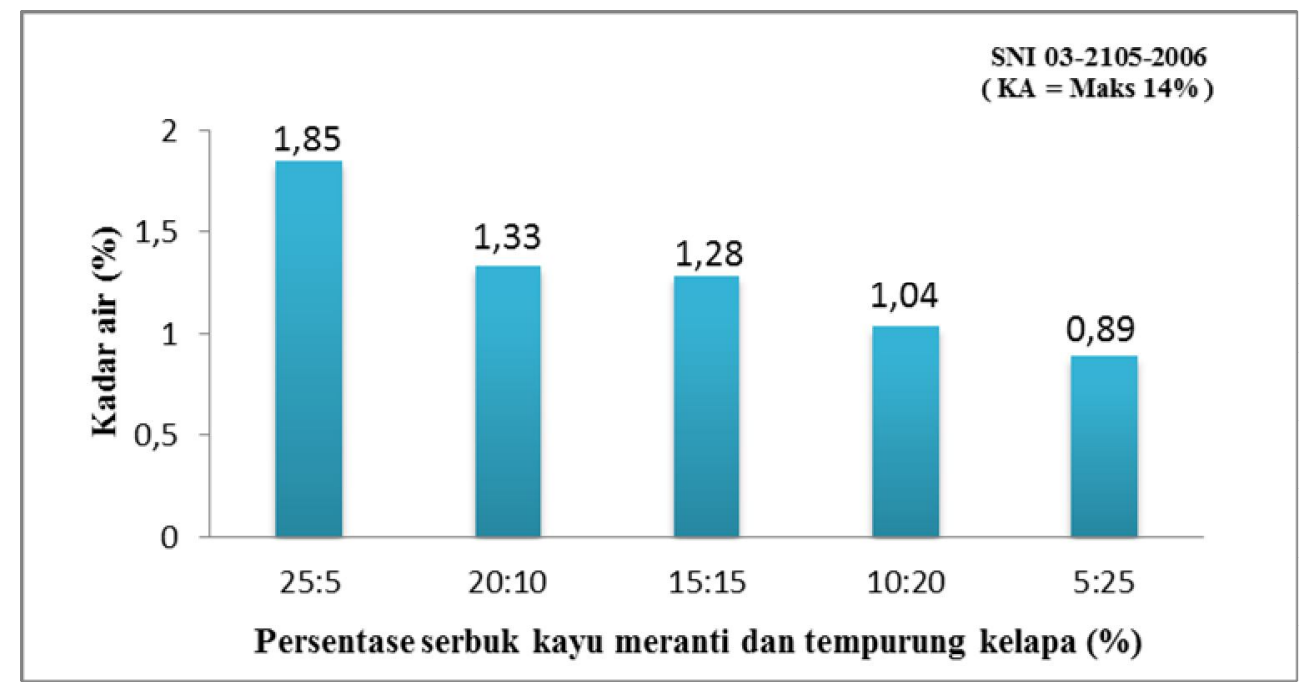

Gambar 2 Pengaruh komposisi serbuk kayu meranti dan tempurung kelapa terhadap kadar air papan partikel

Gambar 2 menunjukkan nilai kadar air papan partikel yang dihasilkan antara 0,89$1,85 \%$. Nilai kadar air terendah papan partikel terdapat pada papan dengan komposisi filler 5:25 yaitu $0,89 \%$, sedangkan nilai kadar air tertinggi papan partikel terdapat pada papan dengan komposisi filler $25: 5$ yaitu 1,85\%. Hasil penelitian memperlihatkan bahwa pengaruh komposisi partikel serbuk kayu meranti dan partikel tempurung kelapa terhadap kadar air dapat dilihat pada penambahan komposisi serbuk kayu meranti, semakin banyak serbuk kayu meranti semakin tinggi kadar airnya. Penambahan partikel serbuk kayu meranti menyebabkan meningkatnya nilai kadar air papan partikel. Hal ini dikarenakan oleh sifat higroskopis ampas tebu yang mudah menyerap air. Kadar air papan partikel juga dipengaruhi oleh kadar air bahan baku. Semakin tinggi kadar air bahan baku semakin tinggi pula kadar air papan partikel yang dihasilkan, karena pada saat proses pengempaan tidak semua uap air yang dikeluarkan dalam papan (Mikael dkk., 2014). Serbuk kayu meranti lebih mudah menyerap air dibanding tempurung kelapa, sehingga nilai kadar air yang didapatkan bertambah seiring dengan penambahana partikel serbuk kayu meranti.

Berdasarkan standar SNI 03-2105-2006 nilai kadar air papan partikel yang ditetapkan tidak melebihi $14 \%$. Nilai kadar air yang didapatkan untuk seluruh variasi komposisi papan partikel yang didapatkan pada penelitian ini memenuhi standar papan partikel. Berdasarkan data kadar air papan partikel di atas, komposisi papan partikel yang terbaik adalah papan partikel dengan perbandingan komposisi 5\% (serbuk kayu meranti) berbanding 25\% (tempurung kelapa) dengan kadar air $0,89 \%$.

\subsubsection{Daya Serap Air}

Daya serap air papan partikel berkisar dari $15,17-34,47 \%$. Nilai daya serap air terendah terdapat pada komposisi 5:25 yaitu $15,17 \%$. Sedangkan nilai daya serap air tertinggi pada komposisi 25:5 yaitu 34,25\%. Hasil pengujian daya serap air ditunjukkan pada Gambar 3. 


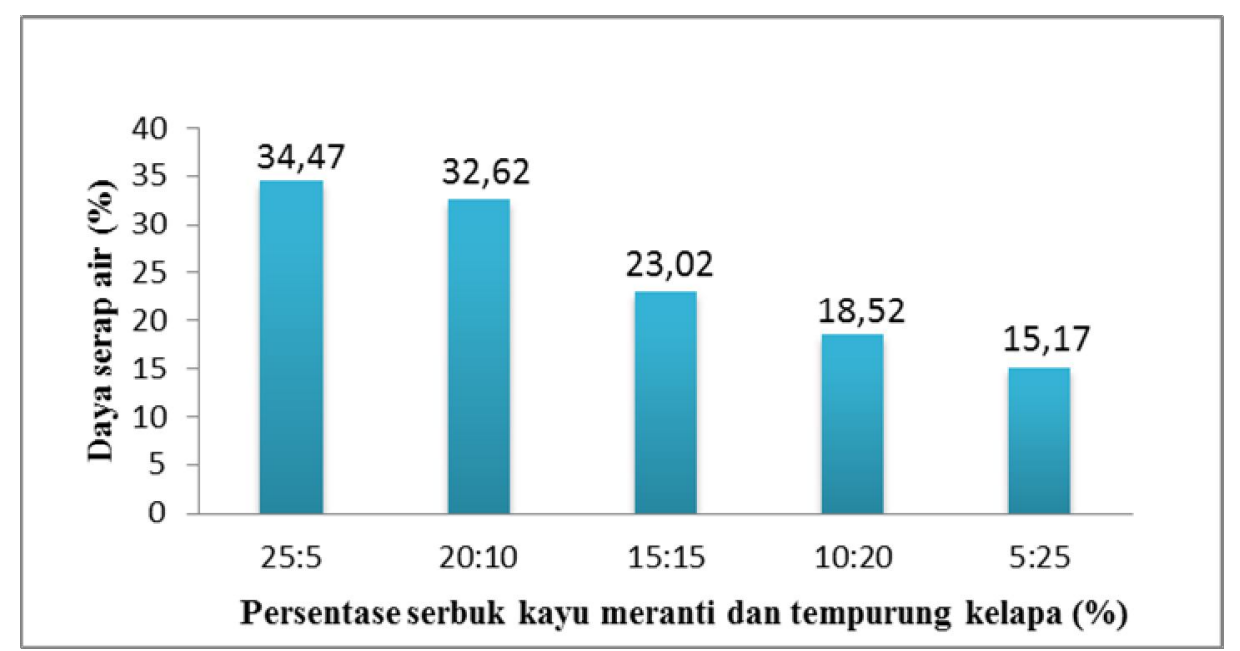

Gambar 3 Pengaruh komposisi serbuk katu meranti dan tempurung kelapa terhadap daya serap air papan partikel

Gambar 3 memperlihatkan komposisi partikel tempurung kelapa yang lebih besar dari komposisi serbuk kayu meranti menyebabkan nilai daya serap air menurun. Hal ini disebabkan karena sedikitnya serbuk kayu meranti yang menyebabkan sifat higroskopis papan partikel semakin rendah. Hal inilah yang membuat ikatan-ikatan berantai antar partikel yang telah terbentuk dalam papan menjadi tidak mudah dirusak oleh air, sehingga daya serap airnya rendah.

Daya serap air berbanding terbalik dengan densitas, semakin tinggi nilai densitas semakin kecil daya serap air (Malau dkk., 2015). Tingginya densitas papan partikel pada penelitian menyebabkan daya serap airnya rendah. Hal inilah yang menyebabkan ikatan antar partikel akan semakin kuat sehingga rongga udara dalam lembaran papan partikel akan semakin kecil. Keadaan tersebut akan menyebabkan air menjadi sulit untuk mengisi rongga pada papan partikel tersebut (Malau dkk., 2015).

Standar SNI 3-2105-2006 tidak mensyaratkan nilai daya serap air, akan tetapi uji nilai daya serap air ini perlu dilakukan karena uji ini dapat digunakan sebagai pertimbangan untuk menentukan penggunaan dari papan partikel ini, apakah layak digunakan pada eksterior atau hanya untuk interior. Berdasarkan hasil pengujian yang menunjukkan nilai daya serap air berkisar 15,17-34,25\%, maka papan partikel ini direkomendasikan untuk keperluan eksterior (Sutigno, 1994). Berdasarkan data daya serap air papan partikel di atas, komposisi papan partikel yang lebih baik dari seluruh variasi pengukuran adalah papan partikel dengan perbandingan komposisi 5\% (serbuk kayu) berbanding 25\% (tempurung kelapa) dengan daya serap air $15,17 \%$.

\subsection{Sifat Mekanik}

\subsubsection{Modulus of Elasticity (MOE)}

Gambar 4 menunjukkan bahwa nilai hasil pengujian MOE antara 396,26-984,93 $\mathrm{kg} / \mathrm{cm}^{2}$. Nilai MOE terendah sebesar 396,26 kg/ $\mathrm{cm}^{2}$ dengan komposisi filler 10:20, sedangkan nilai MOE tertinggi yaitu $984,93 \mathrm{~kg} / \mathrm{cm}^{2}$ dengan komposisi filler 25:5. Nilai MOE papan partikel menurun seiring dengan bertambahnya komposisi tempurung kelapa. 


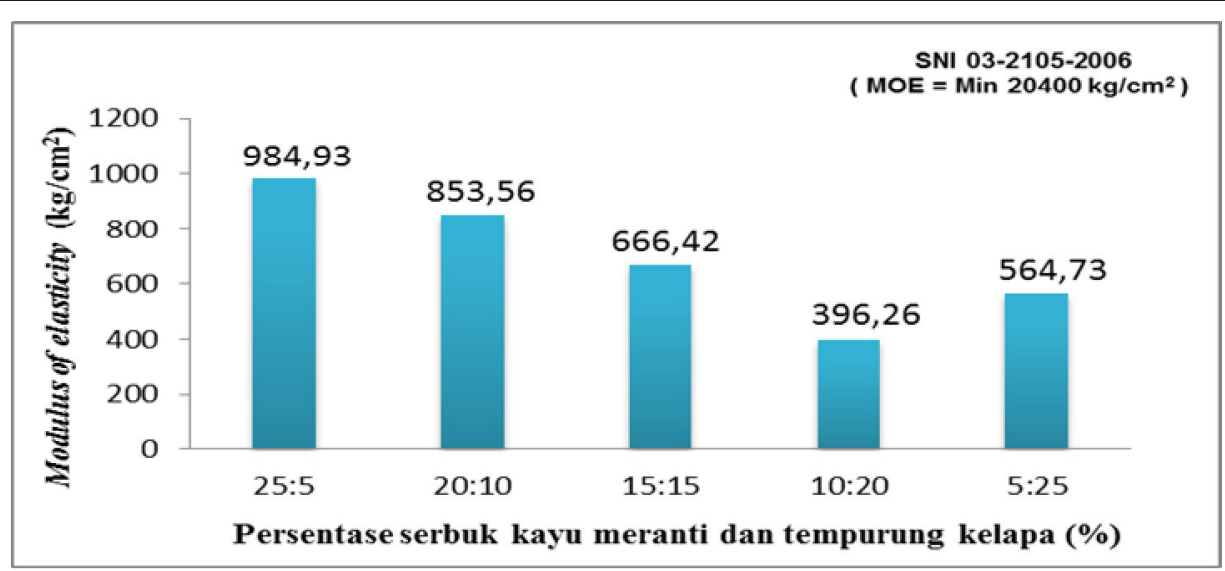

Gambar 4 Pengaruh komposisi serbuk kayu meranti dan tempurung kelapa terhadap MOE papan partikel

Gambar 4 menunjukkan bahwa nilai hasil pengujian MOE antara 396,26-984,93 $\mathrm{kg} / \mathrm{cm}^{2}$. Nilai MOE terendah sebesar 396,26 kg/ $\mathrm{cm}^{2}$ dengan komposisi filler 10:20, sedangkan nilai MOE tertinggi yaitu $984,93 \mathrm{~kg} / \mathrm{cm}^{2}$ dengan komposisi filler 25:5. Nilai MOE papan partikel menurun seiring dengan bertambahnya komposisi tempurung kelapa.

Semua variasi komposisi filler yang dilakukan belum memenuhi standar SNI 03-21052006 yang mensyaratkan nilai MOE papan partikel yaitu minimum $20.400 \mathrm{~kg} / \mathrm{cm}^{2}$. Hal ini diduga disebabkan karena masih banyaknya rongga udara pada papan partikel yang menyebabkan matriks tidak sepenuhnya mengisi ruang kosong pada filler sehingga daya ikat papan partikel masih rendah. Berdasarkan data MOE papan partikel di atas, komposisi papan partikel yang lebih baik dari seluruh variasi pengukuran adalah papan partikel dengan perbandingan komposisi 25\% (serbuk kayu meranti) berbanding 5\% (tempurung kelapa) dengan nilai MOE $984,93 \mathrm{~kg} / \mathrm{cm}^{2}$.

\subsubsection{Modulus of Rupture (MOR)}

Gambar 5 memperlihatkan bahwa MOR sampel yang dibuat berada pada rentang $102,35-199,91 \mathrm{~kg} / \mathrm{cm}^{2}$. Nilai MOR terendah papan partikel terdapat pada papan dengan komposisi filler 10:20 yaitu $102,35 \mathrm{~kg} / \mathrm{cm}^{2}$ sedangkan nilai MOR tertinggi terdapat pada papan dengan komposisi filler $25: 5$ yaitu $199,91 \mathrm{~kg} / \mathrm{cm}^{2}$. MOR papan partikel menurun dengan penambahan massa dari partikel tempurung kelapa.

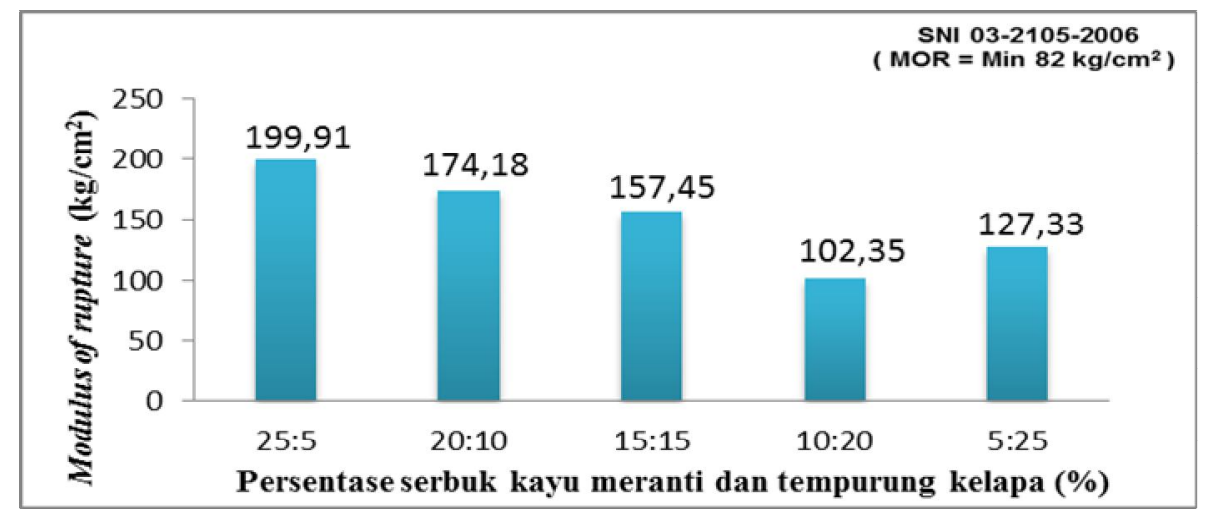

Gambar 5 Pengaruh komposisi serbuk kayu meranti dan tempurung kelapa terhadap MOR papan partikel

Gambar 5 memperlihatkan bahwa MOR sampel yang dibuat berada pada rentang $102,35-199,91 \mathrm{~kg} / \mathrm{cm}^{2}$. Nilai MOR terendah papan partikel terdapat pada papan dengan komposisi filler 10:20 yaitu $102,35 \mathrm{~kg} / \mathrm{cm}^{2}$ sedangkan nilai MOR tertinggi terdapat pada papan dengan komposisi filler 25:5 yaitu $199,91 \mathrm{~kg} / \mathrm{cm}^{2}$. MOR papan partikel menurun dengan penambahan massa dari partikel tempurung kelapa. 
Berdasarkan standar SNI 03-2105-2006 nilai MOR papan partikel yang ditetapkan minimal $82 \mathrm{~kg} / \mathrm{cm}^{2}$. Nilai MOR yang didapatkan untuk seluruh variasi komposisi papan partikel yang didapatkan pada penelitian ini memenuhi standar papan partikel. Berdasarkan data nilai MOR papan partikel di atas, komposisi papan partikel yang lebih baik dari seluruh variasi pengukuran adalah papan partikel dengan perbandingan komposisi 25\% (serbuk kayu meranti) berbanding 5\% (tempurung kelapa) dengan nilai MOR 199,91 kg/ $\mathrm{cm}^{2}$.

\section{KESIMPULAN}

Berdasarkan hasil penelitian yang telah didapatkan, dapat diambil kesimpulan bahwa komposisi partikel serbuk kayu meranti dan tempurung kelapa mempengaruhi sifat fisis dan mekanis papan partikel. Hasil penelitan menunjukkan bahwa pengujian sifat fisis dan mekanis papan partikel telah memenuhi standar SN 03-2105-2006 kecuali pengujian densitass dan MOE. Papan partikel terbaik dalam pembuatan papan partikel yaitu pada komposisi 25\% (serbuk kayu meranti) dan 5\% (tempurung kelapa). Pada komposisi ini papan partikel memiliki densitas yang rendah dan MOE yang tinggi, material yang didapatkan ringan dan kuat.

\section{DAFTAR PUSTAKA}

Cahyana, B.T., "Sifat Fisik dan Mekanik Papan Partikel Tanpa Perekat dari Tandan Kosong Kelapa Sawit", Jurnal Riset Industri Hasil Hutan , 6, 15-26, (2014).

Irawati, F., "Pengaruh Ukuran Serbuk Tempurung Kelapa Sebagai Pengisi Komposit Poliester Tak Jenuh Terhadap Sifat Mekanik dan Penyerapan Air”, Jurnal Teknik Kimia USU, 2, $31-37,(2013)$.

Iswanto, A.H., "Papan Partikel dari Ampas Tebu", Jurnal Ilmu dan Teknologi Kayu, 10, No.4, 103-111, (2009).

Fathanah, U., "Kualitas papan partikel dari Sekam Padi dan Plastik HDPE Daur Ulang Menggunakan Maleic Anhydridre (MAH) sebagai Compatibilizer", Jurnal Rekayasa Kimia dan Lingkungan USK, 8, 53-59, (2011).

Kliwon, S., "Sifat Papan Partikel dari Kayu Mangium", Jurnal Penelitian Hasil Hutan, 20, 195206, (2002).

Malau, J.C. Sucipto, T. Iswanto A.H., "Kualitas Papan Partikel Batang Pisang Barangan Berdasarkan Variasi Kadar Perekat Phenol Formaldehida", Peronema Forestry Science Jurnal, 5, 32-38, (2015).

Maloney, T.M., Modren Particle board and Dry Proces Fiberboard Manufacturing (Miller Freman Inc, San Fransisco, 1997).

Mikael, I. Hartono, R. Sucipto, T., "Kualitas Papan Partikel Dari Campuran Ampas Tebu dan Partikel Mahoni Dengan Berbagai Variasi Kadar Perekat Phenol Formaldehida", Jurnal Kehutanan USU, 5, 1-8, (2014).

Purwanto, D., "Sifat Papan Partikel dari Tandan Kosong Kelapa Sawit dan Serbuk Kayu dengan Perekat Urea Formaldehida", Jurnal Riset Hasil Hutan, 8, 1-8, (2016).

Rizza, S., Kelapa Sawit Upaya Peningkatan Produktivitas, (Erlangga, Yogyakarta, 1994).

Roza, D. Dirhamsyah, M. Nurhaida., "Sifat Fisik Dan Mekanik Papan Partikel dari Kayu Sengon (Paraserianthes Falcataria.L) dan Serbuk Sabut Kelapa (Cocos Nucifera.L)", Jurnal Hutan Lestari, 3, 374-382, (2015).

Standar Nasional Indonesia, Mutu Papan Partikel, SNI 03-2105-2006, (Badan Standar Nasional, Jakarta, 2006).

Sutigno, P., Teknologi Papan Partikel Datar (Pusat Penelitian dan Pengembangan Hasil Hutan dan Sosial Ekonomi Kehutanan, Bogor, 1994). 